УДК 373.3/.5.091.212.012(091)(477)-051Сікорський I.

DOI: https://doi.org/10.35619/iiu.v0i9.125

Міхно Олександр

кандидат педагогічних наук, директор Педагогічного музею України,

Київ, Україна

ORCID: 0000-0002-5271-9530

e-mail:amihno@ukr.net

\title{
ІВАН СІКОРСЬКИЙ (1842-1919) ПРО ЗНАЧЕННЯ ХАРАКТЕРИСТИК УЧНІВ: ТЕОРЕТИЧНИЙ І ПРАКТИЧНИЙ АСПЕКТИ
}

\begin{abstract}
Анотація. Акцентовано, що розгляд проблеми характеристики учня в історико-педагогічному ракурсі ускладнюється змішанням двох суміжних, але по суті різних завдань - психологічного і педагогічного; спільна робота психологів і педагогів дає цінний матеріал для з'ясування психологічних принципів та методів складання характеристик і водночас визначає шлях до вирішення практичних педагогічних завдань. 3'ясовано внесок Івана Сікорського у розроблення проблеми характеристики учня шляхом дослідження теоретичних поглядів та практичної діяльності вченого. Доведено, що виходячи зі своїх уявлень про гармонію в розвитку трьох сфер психіки - розуму, волі й почуття, І. Сікорський наполягав на їх всебічному і комплексному вивченні.

В узагальненому вигляді представлено науковий внесок I. Сікорського у розроблення проблеми характеристики у формі такого ланцюжка взаємопов'язаних дій ученого: проведення першого в світовій педагогіці психолого-педагогічного експерименту $\rightarrow$ визначення теоретичних основ вивчення учня $\rightarrow$ 3'ясування мети складання характеристики 3 наголосом не лише на констатувальному, але й прогностичному іiі характері $\rightarrow$ розроблення плану вивчення дитини (структури майбутньої характеристики).

У формі таблиці подано теоретичні міркування I. Сікорського щодо мети, значення характеристики учня та план вивчення дитини, що водночас становить собою структуру майбутньої характеристики.

Ключові слова: Іван Сікорський, психолого-педагогічний експеримент, характеристика учня, мета характеристики, структура характеристики, методи вивчення учня, значення характеристики.
\end{abstract}

Постановка проблеми. Взаємозв'язок, взаємовплив і взаємозалежність науки i техніки, теорії і практики - це одвічне питання поступу наукового знання. Якщо звернутися до історії науки, скажімо, епохи Відродження, то цей період засвідчив, що наука різко випереджала техніку, але в підсумку техніка також стрімко розвивалася. Принципова різниця між наукою i технікою (теорією і практикою) полягає у тому, що техніка втілює передбачене наукою. Техніка (практика) логічна, вона розвиває (апробує) те, що вже закладено, що вже наявне у теорії. Зайве говорити, що без науки немає техніки, без теорії неможлива ефективна практика. Це аксіома.

Сучасна суспільно-політична, соціально-економічна i соціокультурна ситуація в Україні вимагає посилення зв'язку педагогічної науки і освіти, актуалізує завдання історико-педагогічного дослідження різних форм 
взаємозв’язку педагогічної теорії й освітньої практики. Це стосується усіх педагогічних процесів і явищ, зокрема й такого феномена, як педагогічна характеристика учня. Розгляд проблеми характеристики учня у історикопедагогічному ракурсі ускладнюється змішанням двох суміжних, але по суті різних завдань - психологічного і педагогічного. Аби перевести питання про вивчення учня зі стадії окремих спроб в стадію його вирішення в повсякденній практиці педагога, необхідно чітко розмежувати дві сторони вивчення учня: теоретично-психологічну та практично-педагогічну. Зауважимо, що проблема характеристики учня $\epsilon$ однією 3 тих галузей психології і педагогіки, де зіткнення психологічної теорії 3 педагогічною практикою призводить до результатів, плідних як для теорії, так і для практики. Обмін результатами, отриманими в обох напрямах, взаємна перевірка, i, нарешті, спільна робота психологів і педагогів над загальними питаннями, хоча і з різних точок зору, дають цінний матеріал для 3'ясування психологічних принципів та методів складання характеристик i водночас визначають шлях до вирішення практичних завдань, що стоять в цій галузі перед педагогікою.

В історії української (і європейської) педагогічної науки проблему вивчення учня вперше науково обгрунтував Костянтин Ушинський (1823-1871) у своїй фундаментальній праці «Людина як предмет виховання: досвід педагогічної антропології» (1868-1869). Вчений дав глибоке теоретичне обгрунтування педагогічної антропології як методології вивчення дитини. Антропологічні ідеї К. Ушинського у розрізі вивчення учня 3 подальшим складанням його характеристики знайшли відображення і були розвинені наприкінці XIX - початку XX ст. в працях педагогів і психологів Олександра Віреніуса (1832-1910), Олександра Лазурського (1874-1917), Петра Лесгафта (1837-1909), у науково-педагогічній діяльності Костянтина Єльницького (18461917) та Миколи Грунського (1872-1951), в експериментальних роботах Івана Сікорського (1842-1919).

Аналіз останніх досліджень 3 проблеми. Спадщина Івана Сікорського $\epsilon$ предметом дослідження багатьох сучасних українських учених (Дем'яненко \& Прудченко, 2005; Дічек, 2008, 2012; Леонтьєва, 2012, Менжулін, 2017, Федяєва, 2014, Філімонова, 2005, Янченко, 2017 та ін.). Усі ці праці свідчать, що, по-перше, осягнення сучасними українськими дослідниками наукового доробку Івана Сікорського «має передусім дитиноцентричний характер», i, подруге, серед усієї множини різноманітних аспектів спадщини вченого найуспішнішою виявилася доля його психолого-педагогічних ідей (Менжулін 2017 , с. 74). Саме внесок, зроблений ним у розвиток педагогіки та психології виховання, становить для сучасних українських дослідників найбільший інтерес, а «погляди на дитячий розвиток, його рушійні сили і фактори, мету i засоби виховання, обгрунтовані I. О. Сікорським, заслуговують на високу оцінку сучасних педагогів і психологів» (Дем'яненко \& Прудченко, 2005).

У руслі нашого дослідження відзначимо важливий аспект: зв'язок психолого-педагогічних праць І. Сікорського із розвитком науковоекспериментального напряму в науках про людину. Про це яскраво свідчать такі факти: вчений ще наприкінці 1870-х рр. одним із перших у світовій науці почав застосовувати експеримент для вивчення особливостей дитячої психіки, в 1886 р. заснував при Університеті Св. Володимира одну 3 перших психологічних лабораторій у Російській імперії, а в 1904 р. відкрив у власному 
будинку Лікарсько-педагогічний інститут для розумово недорозвинених, відсталих і нервових дітей.

Наголосимо ще на одній важливій і принциповій обставині. Для вивчення учня 3 подальшим складанням його характеристики потрібні не тільки теоретико-методологічні напрацювання, а й специфічний педагогічний дар, яким Іван Сікорський, безперечно, володів. Окрім того, він мав неабиякі організаційні здібності, що виявилися у діяльності створеного і очолюваного ним Фребелівського педагогічного товариства, а також Фребелівського жіночого педагогічного інституту (1908).

Мета статті полягає у з'ясуванні внеску І. Сікорського у розроблення проблеми педагогічної характеристики учня шляхом дослідження теоретичних поглядів та практичної діяльності вченого.

Виклад основного матеріалу дослідження. Розпочинаючи виклад заявленої у статті теми, підкреслимо, що сам факт значного внеску I. Сікорського у розвиток експериментального вивчення дитини $\epsilon$ нині самоочевидним. Про його першість у здійсненні експериментальних досліджень педагогічних проблем переконливо висловився німецький педагог, теоретик експериментальної педагогіки Вільгельм Лай ще на початку минулого століття (1912, с. 3). Нагадаємо, що власну експериментальну роботу I. Сікорський розпочав у $1870-\mathrm{x}$ роках, коли зайнявся вивченням питання стомлювання учнів гімназії у процесі розумової праці. Сучасна дослідниця психолого-педагогічної спадщини Івана Сікорського Н. Дічек переконливо довела, що «вчений цілеспрямовано здійснив якісно організований масштабний психолого-педагогічний експеримент. Мета експерименту полягала у встановленні факту появи змін у розумовій діяльності учнів протягом шкільних уроків засобом дослідження часткової сфери їхніх психічних проявів, якою вчений обрав письмове мовлення» (Дічек, 2012, с. 91). I. Сікорський пояснив цей вибір наступним чином: по-перше, залишається матеріальна пам'ятка виконаної роботи, по-друге, письмове зображення слова дає змогу зробити його аналіз (Сикорский, 1879, с. 33). Ще однією умовою експерименту став добір виду мовленнєвої роботи: диктант рідною мовою як найменш стомлюючий вид навчальної діяльності. Детально аналізуючи експеримент I. Сікорського 3 позицій сучасного науковця, Н. Дічек підкреслює: «і обгрунтування процедури проведення досліду, i сукупна кількість значень, добутих для вивчення об'єкта, тобто генеральна сукупність, i застосування математичних методів для ії обробки і узагальнення результатів, а також обгрунтування аргументованих висновків - все це свідчить про високий рівень експериментування і про те, що воно виконане на високому науковому рівні, не застаріло і звучить актуально» (Дічек, 2012 с. 92).

Виділимо ще один важливий аспект: у своїй дослідницькій роботі Іван Сікорський використовував різні методи i широке коло різноманітних відомостей про дітей, не обмежуючись лише спостереженням за ними, під час якого фіксував їхні фізичні і психічні властивості і особливості. Зокрема, він детально вивчав обставини життя учнів у навчальному закладі і у дошкільний період. Для створення їхніх психологічних біографій вивчав характеристики, які щороку складали вихователі прогімназії. Крім того, дослідник проаналізував атестаційні зошити, у які записували відомості про успіхи вихованців у навчанні, про їхню поведінку і вчинки (Там само, с. 93). Згадану документацію I. Сікорський вважав надзвичайно «цінним матеріалом для 
розумової і моральної статистики учнів» (Сикорский, 1899, с. 170). Підкреслимо, що спостереження за учнями, вивчення обставин їхнього життя, аналіз шкільної документації про учнів - це важливі методи для складання об'єктивної педагогічної характеристики учня, які пізніше знайдуть своє обгрунтування у працях інших педагогів і застосовуватимуться у практиці роботи вчителя.

Важливими для розуміння внеску І. Сікорського у розроблення проблеми характеристики учня $є$ педагогічні погляди вченого, які й сьогодні вражають актуальністю. Так, визначаючи сучасні йому завдання освіти і роль вчителя в ïx реалізації, I. Сікорський спершу звертає увагу на проблеми вітчизняної освіти, які, на його погляд, до кінця XIX - початку XX століття виразно проявилися в діяльності школи. Передусім, він відзначав, що «основним недоліком середньої школи $\epsilon$ однобічна постановка справи виховання, позбавлена психологічного підгрунтя. Сучасна середня школа бере під свою опіку лише розум, однак майже зовсім забуває про існування почуття і волі у юної людської істоти» (Сикорский, 1909, с. 6). І. Сікорський підкреслював, що згідно з усталеним поглядом «саме завдання гімназій було перекручене: замість навчально-виховних закладів вони перетворені на середні навчальні заклади, вихованець перетворився на учня, а виховання замінилося наглядом i дисципліною; і сам розумовий розвиток перетворений на гімнастику розуму» (Сикорский, 1909, с. 7). Наслідками такої однобічності в роботі школи стало те, що «на арену життя, 3 атестатом зрілості, виступила новоявлена істота 3 дресированим схоластичним розумом, але з недостатнім розвитком почуттів і 3 недостатньою волею» (Там само). Ілюструючи цей висновок, І. Сікорський наводив витяги зі складених комісією з дванадцяти московських професорів на чолі 3 психіатром Сергієм Корсаковим (1854-1900) психологічних характеристик абітурієнтів, що надходили на межі XIX-XX ст. у московські виші. Ці характеристики, запевняв І. Сікорський, «наводять на найсумніші роздуми». Зокрема, в характеристиках зазначається, що у абітурієнтів «самостійність думки не лише не розвинена, але притуплена, не видно звички ні спостерігати явища, ні аналізувати їх комбінації, ні робити узагальнення, ні оцінювати критично чужі думки і слова» (Сикорский 1909, с. 8). Випускники середніх шкіл не вміють висловлювати думки «ясно і правильно». «Саме життя, - підкреслював І. Сікорський, - часто-густо показувало, що вихованець такої школи бував нерідко добре навчений, водночас він залишався позбавленим «здорового глузду» (Там само).

Одним із шляхів виправлення такої ситуації І. Сікорський вважав всебічне вивчення педагогом учня 3 подальшим складанням його характеристики. Вчений наголошував, що «в інтересах виховання варто було б i навіть необхідно робити точні записи, докладні характеристики і описи здібностей, обдарувань і талантів у дітей, так само як їх характеру (курсив наш - О. М.). Це нагальне питання найближчого майбутнього в школі, сім'ї, в житті, основне питання виховання. Поки не будуть вивчені особливості душевного складу і обдарувань і загальний хід їх розвитку, наше виховання буде шаблонним, приблизними, середнім, як мундир солдата, скроєний за загальним розміром (а не за індивідуальною міркою). Але те, що припустимо для костюма, не повинно застосовуватися до живої душі» (Сикорский, 1902, с. $15)$. 
Які ж кроки необхідно зробити для ефективного впровадження характеристики учня у практику роботи школи? На думку, І. Сікорського, розпочинати необхідно із з'ясування поточного стану цієї проблеми i вироблення чіткого плану дій. Учений наполягав, що «для успіху справи перш за все необхідний ясний план, заснований на точному розпізнаванні стану справи. Досі й тому, й іншому не надано належного значення. Спостереження над характером і властивостями дітей з необхідними записами і науковими відомостями зовсім не ведуться в ранній період життя дітей» (Сикорский, 1909, с.85). Перші спроби вивчення дитини і фіксування результатів цього вивчення починаються в школі. «Але й тут, - продовжував І. Сікорський, - існують майже виключно кондуїтні записи і майже не існує нічого схожого на психологічні характеристики. Тоді як лише останні можуть мати значення для виховних цілей» (Там само, с. 86). Такі характеристики, на його думку, необхідні передовсім тому, що лише ними визначається можливість передбачити майбутнє людини, а 3 іншого боку, вони $\epsilon$ безумовним об'єктивним мірилом в руках різних дослідників, дають можливість порівнювати свідчення різних авторів і виводити результат з багатьох джерел; i нарешті тільки психологічна характеристика дає можливість встановити індивідуальність дитини, що є однією 3 важливих практичних вимог школи. Підкреслимо, що Іван Сікорський не обмежувався цими важливими теоретичними міркуваннями, в яких визначав мету характеристики, а й подавав практичні поради до структури характеристики учня, яка має містити відомості про такі основні якості та здібності учня:

1) розумові здібності і ступінь розвитку уваги; в якому напрямку увага розвинена. Особливо ж важливі відомості щодо розумової кмітливості;

2) воля, в сенсі спокійної напруги сил, але не у вигляді поривів. Важливо також збирати відомості про нерішучість, вагання i iнші прояви недорозвиненої волі;

3) розвиток почуттів: а) естетичні почуття, б) інтелектуальні, в) моральні» (Там само, с. 86).

Особливу категорію відомостей характеристики має становити опис ступеня і якості тих почуттів, які є первісними, тобто страху, гніву, печалі і їх похідних - нерішучості, дратівливості, слізливості тощо. Окрему рубрику характеристики учня у баченні І. Сікорського складають дані щодо розвитку почуття сорому і його похідних: сором'язливості, скромності та ін.

Продовжуючи свої дослідження, I. Сікорський у 1912 р. опублікував статтю «План дослідження психічного стану дітей», де зупинився на психічному стані дитини, зокрема пропонував такий порядок його вивчення: 1) інстинктивне життя; 2) воля і рух; 3) розум і пам'ять, тямущість, допитливість; 4) почуття; 5) складний душевний стан, особистість, індивідуальність (Сикорский, 1912).

Отже, І. Сікорський наполягав, що комплексне всебічне вивчення дитини необхідно розпочинати 3 самого іiі народження. Основою цього вивчення зусиллями лікарів, фізіологів, педагогів і психологів має стати «спостереження природного ходу нервово-психічного розвитку дитини і визначення умов, що відповідають цьому розвитку або можуть уповільнювати його» (Сикорский, 1884 , с.21-22). Керуючись власними уявленнями про гармонію в розвитку трьох сфер психіки - розуму, волі й почуття, І. Сікорський акцентував на важливості їх всебічного i комплексного вивчення. Знання вихованців 
допоможе педагогу ставити вимоги, доступні розуму, волі, почуттям учнів, а також не лише усвідомлювати, але і відповідати на всі їхні запити (Сикорский, 1900). Вивчення учня і складання його характеристики має не лише констатувальний, але i прогностичний характер. Педагог, орієнтуючись на наявний рівень розвитку $\mathrm{i}$ прогноз на майбутнє, що відображено у характеристиці, будує систему навчання і виховання дитини. І. Сікорський наполягав на важливості якомога ранніх прогнозів «ще в ту пору, коли вона (дитина) ледь вийшла 3 дитинства, коли вона ще, можливо, не навчилася відрізняти праву руку від лівої, ще не вміє стояти на своїх ногах або вимовляти слова» (Сикорский, 1909, с. 102). Вирішення проблем вивчення педагогом учня i складання його характеристики, вважав учений, лежить у площині педагогічної психології, яка досліджує конкретну дитину, конкретного учня 3 метою пошуку шляхів керівництва його вихованням і навчанням, на відміну від психології теоретичної, що представляє закони розвитку дитини. Автор стверджував про відмінність в характері цілей вивчення дитини вченим i педагогом - науковий і практичний. Додамо, що в своїй особі І. Сікорський поєднав іпостасі вченого і педагога, розробивши як теоретичні аспекти вивчення учня, так і практичні - складання на основі цього вивчення характеристики.

Узагальнимо пропонований І. Сікорським план вивчення дитини та його теоретичні міркування щодо характеристики у формі таблиці:

Таблиця 1

Мета, значення та структура характеристики дитини (за І. Сікорським)

\begin{tabular}{|c|c|}
\hline $\begin{array}{l}\text { Мета та значення } \\
\text { характеристики }\end{array}$ & $\begin{array}{l}\text { складається } 3 \text { виховною метою, є безумовним об'єктивним } \\
\text { мірилом в руках різних дослідників, дає можливість } \\
\text { порівнювати свідчення різних авторів та встановити } \\
\text { індивідуальність дитини, що є однією } 3 \text { важливих практичних } \\
\text { вимог школи; має не лише констатувальний, але і } \\
\text { прогностичний характер }\end{array}$ \\
\hline \multicolumn{2}{|r|}{ Структура характеристики } \\
\hline \multicolumn{2}{|c|}{ Обставини життя учнів у навчальному закладі і у дошкільний період } \\
\hline \multicolumn{2}{|c|}{ Відомості зі шкільної документації про учня (успішність) } \\
\hline \multirow[t]{4}{*}{ Розумові здібності } & ступінь розвитку уваги; в якому напрямі увага розвинена \\
\hline & пам'ять \\
\hline & Кмітливість \\
\hline & Допитливість \\
\hline \multirow[t]{2}{*}{ Воля } & воля, в сенсі спокійної напруги сил, а не у вигляді поривів \\
\hline & нерішучість, вагання та інші прояви недорозвиненої волі \\
\hline \multirow[t]{4}{*}{ Почуття } & $\begin{array}{l}\text { інстинктивні (первісні): страх, гнів, печаль та їх похідні - } \\
\text { нерішучість, дратівливість, слізливість тощо }\end{array}$ \\
\hline & естетичні \\
\hline & Інтелектуальні \\
\hline & $\begin{array}{l}\text { моральні, зокрема розвиток почуття сорому і його похідних: } \\
\text { сором'язливості, скромності та ін. }\end{array}$ \\
\hline
\end{tabular}

Висновки і перспективи подальших розвідок. Підсумовуючи внесок Івана Сікорського у розроблення проблеми характеристики учня, зазначимо, що дослідження вченого були різнобічними й охоплювали всі сторони природи дитини: емоційне життя, розвиток інтелекту, розвиток індивідуальних психологічних рис особистості, формування вольової сфери дитини, 
особливостей розумової праці та розумової втоми, виявлення законів ऑiі перебігу, сприяли створенню нового типу виховання, що грунтується на знаннях психолого-фізіологічних особливостей дитини, а також побудови системи психолого-педагогічного моніторингу для організації оптимальної освітньо-виховної траєкторії конкретного учня.

Загалом, науковий внесок І. Сікорського у розроблення зазначеної проблеми представляємо у формі такого ланцюжка взаємопов'язаних дій ученого: проведення першого в світовій педагогіці психолого-педагогічного експерименту $\rightarrow$ визначення теоретичних основ вивчення учня $\rightarrow$ 3'ясування мети складання характеристики з наголосом не лише на констатувальному, але й прогностичному iï характері $\rightarrow$ розроблення плану вивчення дитини (структури майбутньої характеристики).

Насамкінець відзначимо, що здійснене нами дослідження внеску Івана Сікорського у розроблення проблеми характеристики учня свідчить, що проголошувані ним ідеї за своїм змістом були педологічними і стосувалися дослідження особистості дитини у процесі іï розвитку. Розквіт педології в Україні припадає на 1920-ті - першу половину 1930-х років, коли «виникли й бурхливо розвивалися науки про дитину, які спиралися на експериментальні методи дослідження, природничі науки, і педологія посіла провідне місце серед них...» (Сухомлинська, 2013, с. 387). Це й визначило тему наших подальших наукових пошуків - педологія i питання вивчення учня та складання його характеристики у теорії та практиці 1920-1930-х років.

\section{СПИСОК ВИКОРИСТАНИХ ДЖЕРЕЛ}

Дем'яненко, Н. М., Прудченко, І. І. (2005). Історія вищяої жіночої освіти в Україні: Київський Фребелівський педагогічний інститут (1907-1920рр.): Монографія. Київ: Видавець Л. Галіцина. 492 с.

Дічек, Н. П. (2008). До втілення ідей К. Д. Ушинського про педагогічну психологію: експериментальні дослідження І. О. Сікорського. Шлях освіти. № 3. C. $35-40$

Дічек, Н. П. (2012). Педагогічна антропологія - рушій еволюції вітчизняних педагого-експериментальних досліджень (остання третина XIX - початок XX ст.). Неперервна професійна освіта: теорія і практика. №1-2. С. 88-99.

Леонтьєва, І. В. (2012) Порівняльний аналіз ідей про шкільні характеристики у дослідженнях вітчизняних учених (кінець XIX - початок XX століття). Педагогічна освіта: теорія і практика. Вип. 12. Кам'янець-Подільський. С. 85-92.

Менжулін, В. І. (2017). Постать і спадщина почесного члена Київської духовної академії Івана Сікорського: сучасні інтерпретації. Наукові записки НаУКМА. Філософія та релігієзнавство, 192, С. 73-78.

Федяєва, В.Л. (2014) Сікорський Іван Олексійович (1842-1919) - організатор і голова Київського Фребелівського товариства. Педагогічні науки: зб. наук. праџь. Вип. 65. Херсон: ХДУ, 2014. С. 17-22.

Філімонова, Т.В. (2005) Сікорський Іван Олексійович. Українська педагогіка в персоналіях: навчальний посібник. В 2-х томах. Т. 1. / за ред. О. В. Сухомлинської. Київ: Либідь. С. 525-530.

Янченко Т.В. (2017) Витоки та засади наукового розвитку і практичного втілення педології в Україні: дис... д-ра пед. наук / Янченко Тамара Василівна; наук. консультант Сухомлинська О. В.; Ін-т педагогіки НАПН України. Київ. 529 с.

Лай, А.В. (1912) Экспериментальная педагогика. Москва. 122 с. 
Сикорский, И. А. (1879) О явлениях утомления при умственной работе у детей школьного возраста. Здоровье. Санкт-Петербург: Типография Н.А. Лебедева. T. V. Год 6-й. С. 32-42.

Сикорский, И.А. (1899) О детях трудных в воспитательном отношении. Сборник научно-литературных статей по вопросам общественной психологии, воспитания и нервно-психической гигиены: В 5-ти книгах. Кн. 2. Киев. С. 169-181.

Сикорский, И.А. (1909) Психологические основы воспитания и обучения. Киев. 112 с.

Сикорский, И.А. (1902) Об умственном и нравственном развитии и воспитании детей. Энциклопедия семейного воспитания и обучения. Вып. XLIVXLVI. Санкт-Петербург. 84 с.

Сикорский, И.А. (1912) План исследования психического состояния детей. Дочкольное воспитание. № 1-2. С. 4.

Сикорский, И.А. (1884) Воспитание в возрасте первого детства. СанктПетербург. 203 с.

Сикорский, И.А. (1900) О постановке преподавания и воспитания сообразно ходу умственного развития. Сборник научно-литературных статей по вопросам общественной психологии, воспитания и нервно-психической гигиены: в 5-ти книгах. Кн. 3. Киев-Харьков. С. 137-159.

Сухомлинська, О.В. (2013) Психотехніка і НОП крізь призму диференціації педагогічного процесу в школі у 1920-1930 роках (методологія і технології). Диференційований підхід в історії украӥнської школи (кінець XIX - перша третина XX cm.): Монографія. Київ: Педагогічна думка. С. 373-422.

\section{REFERENCES:}

Demianenko, N. M., Prudchenko, I. I. (2005). Istoriia vyshchoi zhinochoi osvity v Ukraini: Kyivskyi Frebelivskyi pedahohichnyi instytut (1907-1920) [History of Higher Woman's Education in Ukraine: Kyiv Freibele Pedagogical Institute (1907-1920)]. Kyiv. 492 s. [in Ukrainian].

Dichek, N. P. (2008). Do vtilennia idei K. D. Ushynskoho pro pedahohichnu psykholohiiu: eksperymentalni doslidzhennia I.O.Sikorskoho [To the Implementation of the Ideas of K.D. Ushinskyi about Pedagogical Psychology: Experimental Research by I. O. Sikorsky]. Shliakh osvity. No 3. S. 35-40. [in Ukrainian].

Dichek, N. P. (2012). Pedahohichna antropolohiia - rushii evoliutsii vitchyznianykh pedahoho-eksperymentalnykh doslidzhen (ostannia tretyna XIX pochatok XX st.) [Pedagogical Anthropology as the Engine of the Evolution of Ukrainian Pedagogical-experimental Research (the last third of the 19th - the beginning of the 20th century)]. Neperervna profesiina osvita: teoriia i praktyka. No 1-2. S. 88-99. [in Ukrainian].

Leontieva, I. V. (2012) Porivnialnyi analiz idei pro shkilni kharakterystyky u doslidzhenniakh vitchyznianykh uchenykh (kinets XIX - pochatok XX st.) [Comparative Analysis of Ideas of School Characteristics in Researches of Ukrainian Scientists (the end of the 19th and beginning of the 20th centuries)]. Pedahohichna osvita: teoriia i praktyka. Vyp. 12. Kamianets-Podilskyi. S. 85-92. [in Ukrainian].

Menzhulin, V. I. (2017). Postat i spadshchyna pochesnoho chlena Kyivskoi dukhovnoi akademii Ivana Sikorskoho: suchasni interpretatsii [The Figure and Heritage of an Honorary Member of the Kiev Theological Academy, Ivan Sikorskyi: Modern Interpretations]. Naukovi zapysky NaUKMA. Filosofiia ta relihiieznavstvo. 192. S. 73-78. [in Ukrainian].

Fediaieva, V.L. (2014). Sikorskyi Ivan Oleksiiovych (1842-1919) - orhanizator i holova Kyivskoho Frebelivskoho tovarystva [Sikorskyi Ivan Oleksiiovych (1842-1919) - 
Organizer and Head of Kyiv Froebel Society]. Pedahohichni nauky. Vyp. 65. Kherson: KhDU, 2014. S. 17-22. [in Ukrainian].

Filimonova, T.V. (2005). Sikorskyi Ivan Oleksiiovych. Ukrainska pedahohika $v$ personaliiakh. T. 1. Kyiv: Lybid. S. 525-530. [Ukrainian].

Yanchenko, T. V. (2017). Vytoky ta zasady naukovoho rozvytku i praktychnoho vtilennia pedolohii $v$ Ukraini [Origins and Principles of Scientific Development and Practical Implementation of Pedology in Ukraine]. Doktor pedagogichnykh nauk. Instytut pedahohiky NAPN Ukrainy. Kyiv. [in Ukrainian].

Lay, A.V. (1912). Eksperimentalnaya pedagogika [Experimental Pedagogy]. Moskva. 122 s. [in Russian].

Sikorskiy, I. A. (1879). O yavleniyakh utomleniya pri umstvennoy rabote u detey shkolnogo vozrasta [On the Phenomena of Fatigue in the Process of Mental Work in Schoolchildren]. Zdorovye. Sankt-Peterburg: Tipografiya N.A. Lebedeva. T. V. God 6. S. 32-42. [in Russian].

Sikorskiy, I.A. (1899). O detyakh trudnykh v vospitatelnom otnoshenii [About difficult children in the educational relation]. Sbornik nauchno-literaturnyh statey po voprosam obshchestvennoy psikhologii. vospitaniya i nervno-psikhicheskoy gigiyeny: $\mathrm{V}$ 5-ti knigakh. Kn. 2. Kiev. S. 169-181. [in Russian].

Sikorskiy, I.A. (1909). Psikhologicheskiye osnovy vospitaniya i obucheniya [Psychological Foundations of Education and Training]. Kiev. 112 s. [in Russian].

Sikorskiy, I.A. (1902). Ob umstvennom i nravstvennom razvitii i vospitanii detey [On the Mental and Moral Development and Education of Children]. Entsiklopediya semeynogo vospitaniya $i$ obucheniya. Vyp. XLIV-XLVI. Sankt-Peterburg. 84 s. [in Russian].

Sikorskiy. I.A. (1912). Plan issledovaniya psikhicheskogo sostoyaniya detey [Plan of the Study of Mental State of Children]. Doshkolnoye vospitaniye. No 1-2. S. 4. [in Russian].

Sikorskiy, I.A. (1884) Vospitaniye v vozraste pervogo detstva [Education at the Age of the First Childhood]. Sankt-Peterburg. 203 s. [in Russian].

Sikorskiy, I.A. (1900). O postanovke prepodavaniya i vospitaniya soobrazno khodu umstvennogo razvitiya [On the Formulation of Teaching and Education according to the Mental Development]. Sbornik nauchno-literaturnykh statey po voprosam obshchestvennoy psikhologii. vospitaniya i nervno-psikhicheskoy gigiyeny: v 5-ti knigakh. Kn. 3. Kiev-Kharkov. S. 137-159. [in Russian].

Sukhomlynska, O.V. (2013). Psykhotekhnika i NOP kriz pryzmu dyferentsiatsii pedahohichnoho protsesu v shkoli u 1920-1930 rokakh (metodolohiia i tekhnolohii) [Psychotechnics and NOP through the Prism of the Differentiation of the Pedagogical Process in School in 1920-1930 (Methodology and Technology)]. Dyferentsiiovanyi pidkhid $v$ istorii ukrainskoi shkoly (kinets XIX - persha tretyna XX st.). Kyiv: Pedahohichna dumka. S. 373-422. [in Ukrainian].

\section{IVAN SIKORSKYI (1842-1919) ON THE IMPORTANCE OF STUDENTS' CHARACTERISTICS: THEORETICAL AND PRACTICAL ASPECTS}

Oleksandr Mikhno,

Candidate of Pedagogical Sciences, Director at Pedagogical Museum of Ukraine,

Kyiv, Ukraine

ORCID: 0000-0002-5271-9530

e-mail:amihno@ukr.net 


\begin{abstract}
It is emphasized that consideration of the issue of students' characteristics in the historical and pedagogical perspective is complicated by the mixing of two adjacent, but essentially different tasks — psychological and pedagogical; the joint work of psychologists and educators provides valuable material for the elucidation of psychological principles and methods of compiling characteristics and at the same time defines the path to solving practical pedagogical tasks. The contribution of Ivan Sikorsky to the development of the problem of the students' characteristics through the study of theoretical views and practical activities of the scientist is determined.

It is proved that I. Sikorsky combined the hypostasis of a scientist and a teacher in his person, developing both theoretical and practical aspects of studying a srudent, compiling the characteristics on the basis of this study. Proceeding from his ideas about harmony in the development of the three spheres of the psyche — reason, will and feeling, the scientist insisted on their comprehensive study by the methods of experiment, observation, studying the circumstances of life of children in preschool and school periods, analysis of school documentation about pupils.

In a generalized form, the scientific contribution of I. Sikorsky to the development of the issue of characteristics in the the form of such a chain of interrelated actions of the scientist: conducting the psychological and pedagogical experiment which was the first in the world pedagogy $\rightarrow$ the definition of the theoretical foundations of studying the pupil $\rightarrow$ clarification of the purpose of compiling the character reference with emphasis not only on ascertaining nature, but also on its forecasting nature as well $\rightarrow$ developing a plan for studying the child (the structure of the future character reference).

The table shows the theoretical arguments of I.Sikorsky concerning the purpose, the value of the students' characteristics and the plan for studying the child, which is a structure of the future characteristics at the same time.

It is emphasized that the study of the student and the compilation of his characteristics, according to I. Sikorsky, has not only a statement but also a forecasting character, when the teacher, guided by the existing level of development and the forecast for the future, reflected in the character reference, builds a system of education of a particular pupil.
\end{abstract}

Key words: Ivan Sikorsky, psychological-pedagogical experiment, students's characteristics, aim of the characteristics, structure of characteristics, methods of studying the students, importance of the characteristics,

Стаття надійшла до редакиії 08.04.2019 p. 